\title{
POLYNEURITIS IN HAEMOCHROMATOSIS
}

\author{
S. C. Melnick, B.Sc., M.B., M.R.C.P. \\ Feff Hall Research Fellow \\ A. G. W. Whitfield, M.D., Ph.D., F.R.C.P. \\ Physician \\ From the Department of Medicine, Queen Elizabeth Hospital, University of Birmingham and the Birmingham Region
} Virus Laboratory

IN the literature on hæmochromatosis, reference to involvement of the central nervous system is scanty. Sheldon (1935) in his classic monograph describes iron deposits in the pituitary, the pineal, the choroid plexus and the olfactory bulb but makes no mention of clinical neurological manifestations. Cammermayer (1947) recorded an autopsy in which pigmentation was present in the pituitary, pineal, choroid plexus, leptomeninges, lentiform and dentate nuclei, and fourth ventricle, and Mallory, Parker and Nye (1920) found hæmosiderin and hæmofuchsin in peripheral nerves. Lewey and Govons (1942) described a patient with deafness, cerebellar signs, a spastic paraplegia and a neurogenic bladder of five years duration in whom the autopsy showed hæmochromatotic pigmentation of the meninges, the cerebellum, the brain stem and the spinal cord. There was no clinical evidence of hæmochromatosis and the viscera were not examined at the postmortem. A similar case was recorded by Neumann (1948). There was a long history of cerebellar ataxia, deafness and depression attributable at autopsy to hæmochromatotic involvement of the brain particularly the cerebellum and the roof of the fourth ventricle, but the liver was normal. Cachera and Lamotte (I 948) described a patient with liver cirrhosis and hæmochromatosis, paroxysmal diplopia and a central vestibular syndrome, the neurological abnormalities disappearing with thyroid and steroid therapy. Sherlock (1958) mentioned the occurrence of psychic disturbances and peripheral neuritis, the latter being usually attributable to the diabetic component (Sherlock, 196I), while Finch and Finch (1955) in their study of 80 patients suffering from hæmochromatosis found peripheral neuritis in $14 \%$ and consider that it does not always occur as a sequel to diabetes.

This communication records the occurrence of severe polyneuritis in a woman suffering from hæmochromatosis. Iron was demonstrated in the peripheral nerves and complete neurological recovery followed steroid therapy.

\section{Case Report}

A married woman, aged 43, was admitted to the Queen Elizabeth Hospital, Birmingham, in November 1959. She gave a history of three miscarriages; her fourth pregnancy in 1952 had culminated in toxæmia and an accidental hæmorrhage at the sixth month and hysterotomy had been performed to remove a dead foetus. There had been numerous attacks of phlebothrombosis in the legs and for some years her ankles and lower legs had been œdematous and discoloure $\vec{s}$ During the previous 16 years she had had four episodes of jaundice and a cholecystography had shown a noţ functioning gall bladder. For six years she had been lacking in energy and had suffered upper abdoming pain more on the left side than the right and sometimgs associated with nausea and vomiting.

Examination showed bilateral ankle œdema ang generalized slaty pigmentation maximal on the face and neck. There was nothing abnormal found in the abdomen or pelvis and the urine was free from albumin and sugar. The chest, cardiovascular and central nervoeg systems were normal.

\section{Investigations}

Liver function tests showed an albumin of $3.7 \mathrm{~g} . / 1 \ddot{\square}$ $\mathrm{ml}$. and a globulin of $3.7 \mathrm{~g}$. $/ 100 \mathrm{ml}$. (gamma globuli 1.0 g. (alcohol method) and $2.4 \mathrm{~g}$. (ammonium sulpha? method)) and a bilirubin of $1.1 \mathrm{mg} . / 100 \mathrm{ml}$., but wepe otherwise normal. The prothrombin time was $15 \mathrm{gec}$ (control $12 \mathrm{sec}$.). The serum haptoglobulins tweff normal. The hæmoglobin was $94 \%$, the white brod cells 4,900 per mm. ${ }^{3}$ and the differential count not The serum iron and the serum iron binding capatiog were $187 \mu \mathrm{g}$./ $100 \mathrm{ml}$. Red cell fragility was normal, the Coombs test negative and Schumm's test positive. Sternal puncture showed free iron in smears and sections and an increased number of plasma cells of varying siae and morphology, some with double nuclei. Many fret nuclei, presumably from such cells, were present, othe $\overrightarrow{5}$ wise no abnormalities were found. An oral glucose tolerance test was normal. The urine containes melanogen and hæmosiderin. The blood urea was $\mathrm{mg}$./ $100 \mathrm{ml}$. Chest radiograph: normal. ECG: physio' logical. Blood group: A rhesus negative.

\section{Operation}

Laparotomy showed a cirrhotic liver and a dilated ga्र. bladder. The common bile duct, which was not dilated, was explored and found free from stones and obstruction. The gall bladder was removed (it contained no stones) and liver and skin biopsies were performed. Histolog of the gall bladder showed chronic cholecystitis, white the liver showed advanced multilobular cirrhosis. The fibrous trabeculæ were highly cellular and contain both fibroblasts and chronic inflammatory cells, togethet with proliferating bile ducts. Large amounts of iron pigment were present in the liver cells, the Kupfer ce and within macrophages in the fibrous tissue (Fig. N The skin showed prominent melanin pigmentation in the basal cells of the epidermis and iron pigment was presen, being mainly concentrated around the sweat gland duoss in the dermis (Fig. 2).

\section{Progress}

During the subsequent 18 months she had repeateg venesections. The urine remained free from sugar, b $\mathrm{ft}^{t}$ she continued to suffer attacks of left upper abdominal 


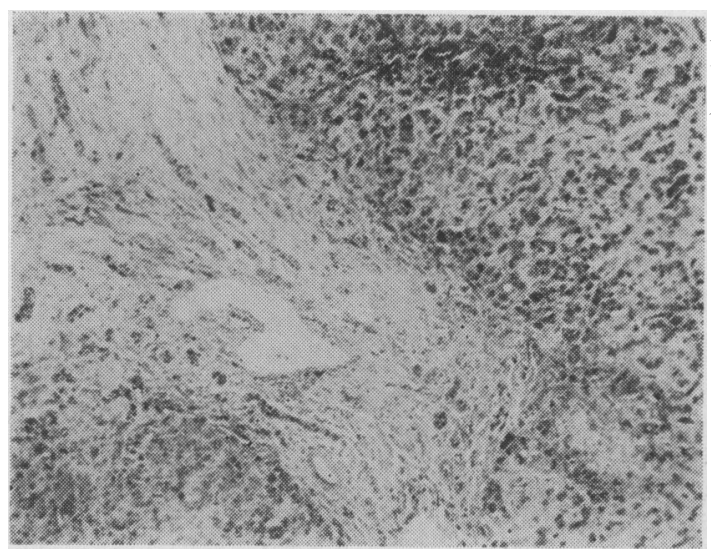

FIG. 1.-Liver showing wide fibrous trabeculæ containing proliferating bile ducts. Liver parenchyma heavily infiltrated with iron pigment, which is shown both in liver cells and Kupfer cells. Perl's stain $\times 70$.

pain. During the early months of 1961 she was troubled by cramps in her legs and noticed weakness of her legs on physical effort, such as dancing. On May 7 she had an injection of poliomyelitis vaccine and two weeks later she developed pain and stiffness in her legs and pain in the neck, back and arms. The arms and legs became progressively weaker and more painful and analgesic tablets containing aspirin were administered. Hæmatemesis and melæna followed their ingestion and she was readmitted as an emergency on May 28, r 961 . Blood loss cannot have been gross, as the lowest hæmoglobin recorded was $70 \%$. During the subsequent two weeks pain in the limbs and trunk was severe enough to require the frequent administration of methadone and there was progressive weakness of the musculature of all four limbs and the trunk. Loss of power never became absolute, but she was unable to sit up, to lift her arms above her head, to use her hands for any purpose or to lift her legs from the bed. Involvement of the respiratory muscles led to some collapse at both lung bases, but assisted respiration was never required. The sphincters were not involved. All tendon jerks were lost and the limbs showed peripheral sensory impairment of all modalities. Prednisone was commenced in a dose of 40 mg. daily on June 3,1961 , and two weeks after admission the downward course halted and pain, muscle weakness and sensory loss began to regress; when she was discharged from hospital on August i4 all neurological symptoms and signs had disappeared and there has been no recurrence. At no time during the illness was there any pyrexia, but shortly after her admission there was a transitory increase in the white cell count $(13,000$ per $\left.\mathrm{mm} .^{3}\right)$ and in the sedimentation rate $(41 \mathrm{~mm} . / \mathrm{hr}$., Wintrobe). The CSF showed a pressure of $220 \mathrm{~mm}$. of water and a protein of $55 \mathrm{mg}$./ $100 \mathrm{ml}$., but was otherwise normal. No cytopathogenic virus was isolated from the cerebrospinal fluid nor from throat swabs, nasal swabs or fæces. Repeated complement fixation tests on the blood showed no significant titre to any known virus, while the only positive findings in respect of autoimmune antibodies were a titre of $I$ in 16 against liver and of 1 in 32 against spinal cord on May 30, 1961. Both had fallen to 1 in 8 by July 10,1961 . Electro-diagnostic studies performed six weeks after readmission to hospital showed moderate uniformly delayed conduction along the left ulnar nerve (conduction time $40 \mathrm{~m}$./ $/ \mathrm{sec}$. (normal

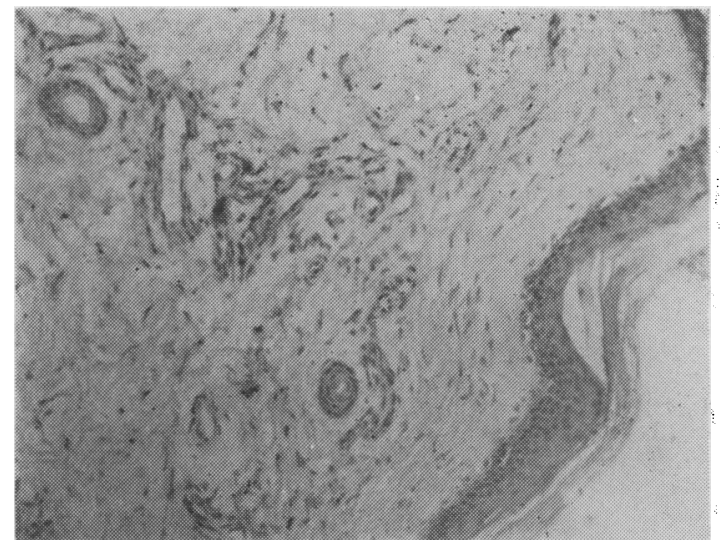

FIG. 2.-Skin showing deposits of iron pigment around sweat gland duct; and diffusely in the dermis. Perl's stain $\times$ 100.

$54 \mathrm{~m} . / \mathrm{sec}$.$) ) and a normal strength duration curve in$ the right and left palmaris longus. Electromyography from the left palmaris longus showed the pattern of established reinnervation, that is polyphasic potentials of both high and low voltage with normal duration in $40 \%$ of the potentials recorded and a full interference pattern. The left hypothenar eminence showed evidence of recent denervation in that $50 \%$ of the potentials recorded were polyphasic and nearly all were of abnormally low voltage and short duration. Muscle biopsy from the right palmaris longus showed no abnormality in hæmatoxylin and eosin preparations, but staining with prussian blue showed iron in the axons of motor nerve fibres (Figs. 3 and 4). Vital staining with methylene blue using squash preparations demonstrated a pale staining diffuse swelling of some nerve fibres and finely beaded regenerating nerve fibres. Motor end plates were unduly elaborate and showed dark staining swelling of the terminal expansions and arborizations (Fig. 5), with some evidence of collateral sprouting (Fig. 6). Osmic acid preparations from a subcutaneous sensory nerve showed loss of nerve fibres more evident in small fibres than large. Repeated examination of the urine showed no porphyrins or porphobilinogen.

During this second period in hospital clinical and laboratory assessment showed no significant change in the hæmochromatosis from the findings 18 months previously. Steroid therapy produced some glycosuria, but this disappeared as the prednisone was withdrawn. A barium meal revealed no œsophageal varices and no ulcer or hiatus hernia, but both micropaque and raybar showed a general dilation of the small intestine with prominence of plicæ and poor secondary arborizations. A fat balance, however, showed a stool content of only $3.56 \mathrm{~g}$. of fat per day and microscopy of the fæces showed no excess of fat, fatty acid or meat fibres.

An acute polyneuritic illness in which no aetiological factor can be identified is a well recognized and not uncommon clinical entity. It usually occurs in otherwise healthy individuals and in the patient here described it may well have been unassociated with the hæmochromatosis from which she had suffered for so many years. However, the finding of iron in the peripheral nerves, though 

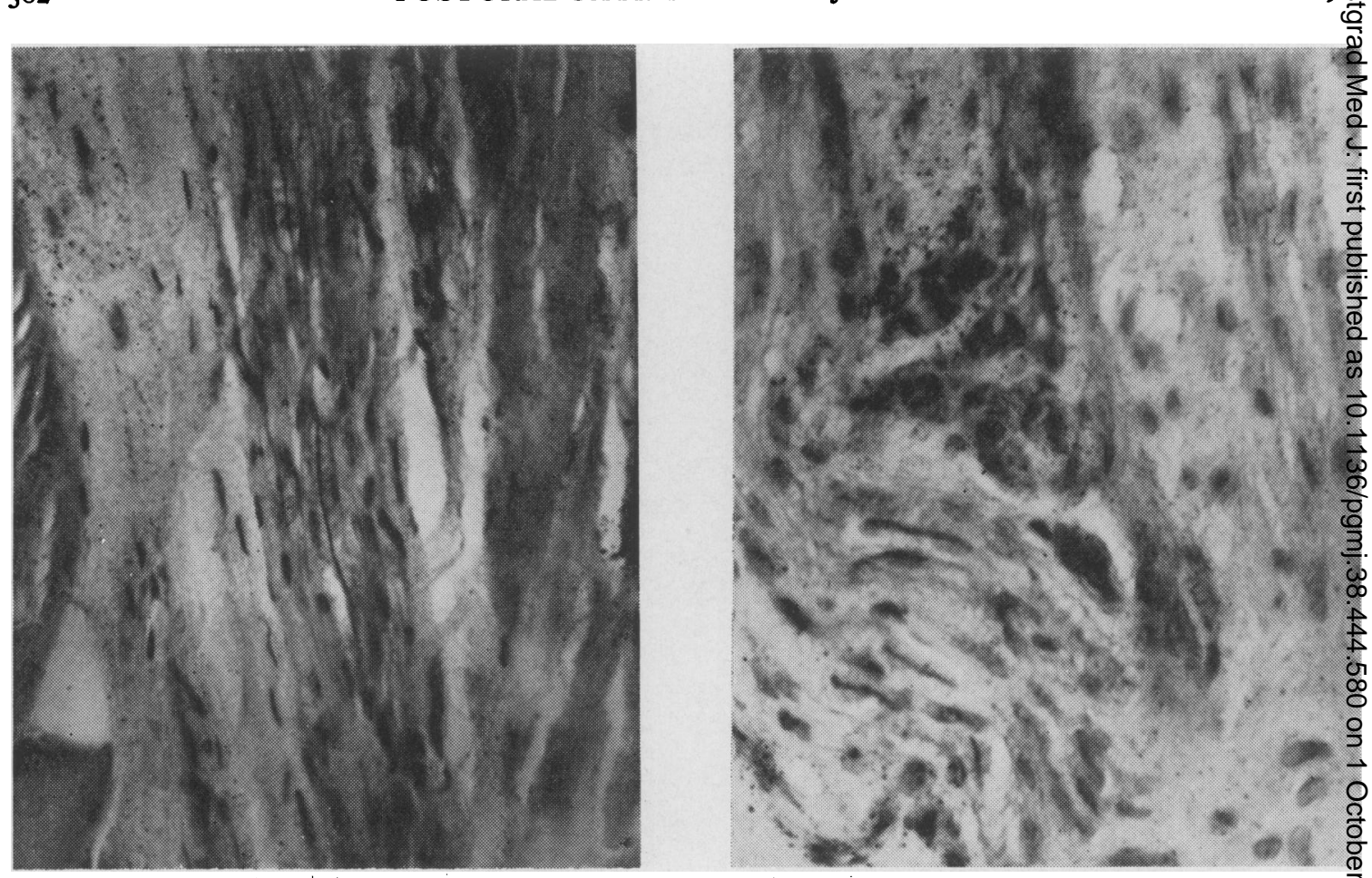

FIGS. 3 and 4.-Intramuscular nerve showing the presence of iron. Prussian blue stain.

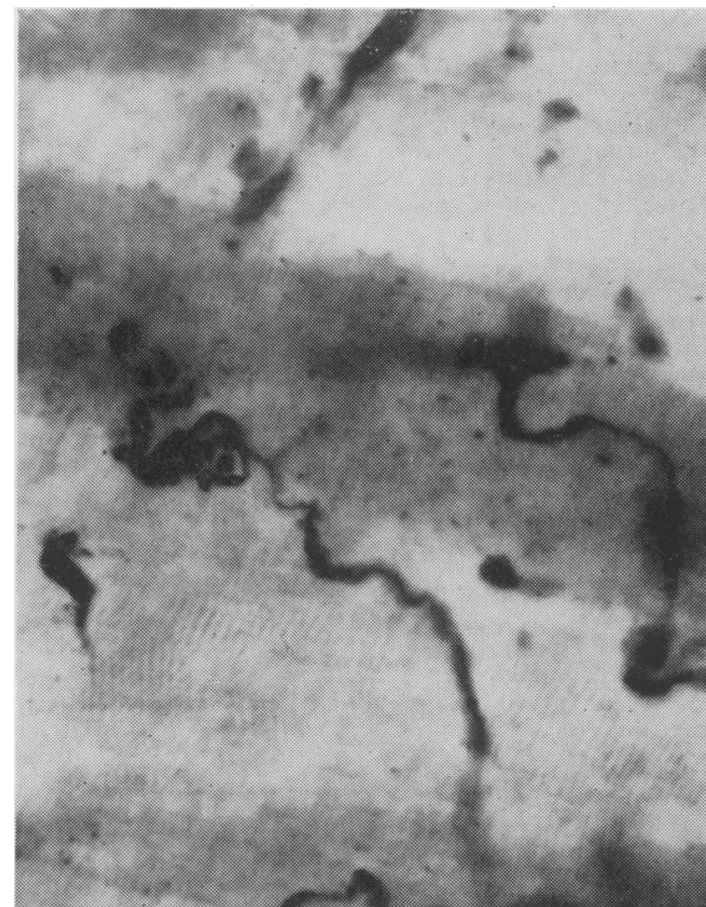

Fig. 5.-Unduly elaborate motor end plate with dark staining swelling of the terminal expansions and arborizations. Methylene blue. Squash preparation.

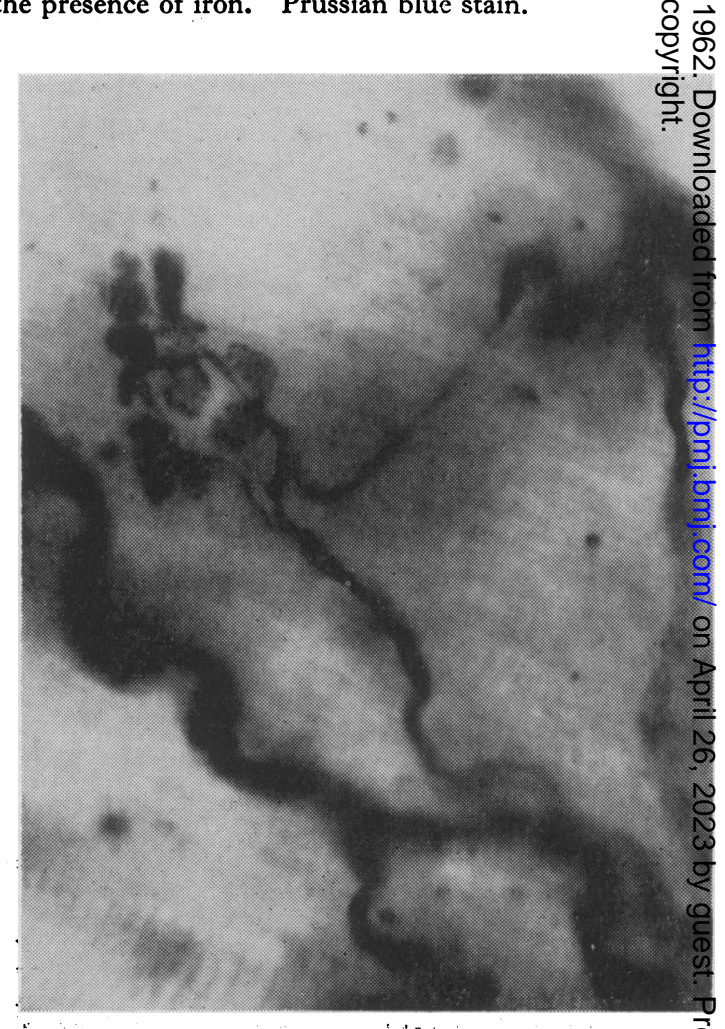

FIG. 6.-Motor end plate showing collateral sprouting Methylene blue. Squash preparation. 
described once previously (Mallory, Parker and Nye I920) is a little known feature of hæmochromatosis and its presence inevitably suggests that it may have been the cause of the peripheral neuropathy. Finch and Finch (1955) found peripheral neuritis fairly commonly in the group of cases of hæmochromatosis they studied and were not always able to attribute it to the diabetic component of the disease. However, if the iron in the peripheral nerves was responsible for the polyneuritis in the case here reported it is difficult to explain the rather acute onset and the relatively rapid and complete recovery. To what extent the latter was a result of steroid therapy it is of course impossible to say but it is perhaps significant that in the case of hæmochromatosis described by Cachera and Lamotte (1948) complete recovery from paroxsymal diplopia and a central vestibular syndrome followed the administration of steroids.

It is not thought that the injection of poliomyelitis vaccine played any part in the illness as it appears to have begun before the injection was given and the negative virus studies and the presence of sensory loss are against such an explanation. Nor can diabetes have been in any way responsible as the only evidence of it was transitory glycosuria whilst large doses of prednisone were being administered. Although radiologically the small bowel appearances suggested malabsorption the fat balance and stool microscopy showed no abnormality and the neurological illness was quite unlike those described in steatorrhœea. Smith (196r) described a patient with hæmochromatosis who developed hepatic carcinoma and a myopathy but the recovery and present well being of the patient here described belies the presence of any malignant change in her liver or of any neoplastic process elsewhere.

The positive findings in respect of auto-immune antibodies to spinal cord are of interest as this has been a feature of a group of cases of the Guillain Barré syndrome recently studied (Melnick, in the press).

We are greatly indebted to Dr. T. H. Flewett in whose laboratory the serological studies were carried out, to Dr. A. L. Woolf for the muscle biopsy and to Dr. D. J. Parish for Figs. I and 2.

\title{
REFERENCES
}

Cachera, R., and Lamotte, M. (1948): Myxœdème et Signes Neurologiques Associés au Cours d'une Cirrhose Pigmentaire, Paris méd., 38, 445.

Cammermayer, J. (1947): Deposition of Iron in Paraventricular Areas of the Human Brain in Hemochromatosis, f. Neuropath. exp. Neurol., 6, 111 .

FincH, S. C., and FINCH, C. A. (1955): Idiopathic Hemochromatosis, Medicine (Baltimore), 34, 381.

Lewey, F. H., and Govons, S. R. (1942): Hemochromatotic Pigmentation of the Central Nervous System, F. Neuropath. exp. Neurol., I, 129.

Mallory, F. B., Parker, F., and Nye, R. N. (1920): Experimental Pigment Cirrhosis due to Copper and its Relation to Hemochromatosis, $\mathcal{Y}$. med. Res., 42, 46r.

Melnick, S. C.: 38 Cases of the Guillain Barré Syndrome, An Immunological Study, Brit. med. F. In press.

Neumans, M. A. (1948): Hemochromatosis of the Central Nervous System, $\mathcal{F}$. Neuropath. exp. Neurol., 7, 19.

ShELdON, J. H. (1935): ' Hæmochromatosis'. London: Oxford University Press.

SHERLOCK, S. (1958): 'D Diseases of the Liver and Biliary System '. Oxford: Blackwell.

- (196I): Personal communication.

Sмiтh, W. T. (1961): Neurological Disorders Associated with Malignant Disease, Postgrad. med. F., 37, 282.

\section{A PANCREATIC NEOPLASM PRESENTING WITH HYPERCALCAEMIA}

\author{
J. L. Craven, B.Sc., M.B., Ch.B. \\ Late House Physician, St Mary's Hospital, Portsmouth*
}

THE association of hypercalcæmia with malignant disease has usually been attributed to metastases in bone. Recently, however, there has been reported a small number of cases in which secondary deposits in bone were not found and the hypercalcæmia was considered to be a primary effect of the tumour. This communication is concerned with such a case and reported because of its rarity and interest.

* Now at the Department of Anatomy, University College, I.ondon.

\section{Case History}

A 66-year-old married woman was admitted to St. Mary's Hospital, Portsmouth, on April 22, 196r and died 12 days later. She was unable to give a lucid history, but from relatives it was learned that she had been in good health until June 1960, when she first complained of pain in the left side of her chest and in the left hypochondrium. The pain was persistent, slight and not relieved by alkalis or other simple measures. Some three months later she had an attack of apparent ' pyelitis ',with fever, dysuria and hæmaturia for three days. It responded to sulphonamide therapy given by her own doctor. Since this time she had complained of post-prandial pain in the left hypochondrium 